\title{
ANALISIS PENYIMPANGAN TUGAS DAN FUNGSI PUBLIC RELATIONS DALAM MEMBENTUK CITRA PERUSAHAAN
}

\author{
Angga Intueri Mahendra Purbakusuma \\ Fakultas Ilmu Komunikasi Universitas AMIKOM Yogyakarta \\ Jl. Ring Road Utara, Condong Catur, Sleman, Yogyakarta, Indonesia \\ Telp. (0274) 884201-207 \\ Email: angga_intuery@amikom.ac.id
}

\begin{abstract}
Practice of Public Relations have recently tended to blur the original concept launched by Public Relations founders. Even though a practice of a Public Relations take a crucial role in run management functions so that the relationship between the companies concerned with the public can be harmoniously intertwined. Hence, the purpose of this research is to determining how the form of deviations from duties and functions of Public Relations in build corporate image. The research was conducted using a qualitative approach with descriptive methods, descriptive analysis which describes the role of Operational Secretary (OPS) as Public Relations in enhancing the corporate image for a supplier company engaged in construction services business in Batam and the data analysis techniques used by investigators are components of the data analysis by Miles and Huberman Interactive Model. The results of this research indicate that the implementation of the duties and functions of Public Relations as an effort to build corporate image. Implementation of Public Relations activities can not be said optimal because does not have a special section in handling the tasks and functions of Public Relations, but delegate tasks and functions of Public Relations is the Operational Secretary (OPS). The absence of a separate section of Public Relations, limited resources that can be used, and other administrative work that must be done by Operational Secretary (OPS) which takes time and focus is the obstacle faced by Operational Secretary (OPS) in performing duties and functions as Public Relations. The conclusion of this research shows that public relations is a very important to role in build a corporate image. Public Relations role maintaining good communication and relationship with internal and external public companies, to increase the company's existence. With emphasis on quality of service for consumers, establish good relationships with various public companies and tried to give a good impression in the community. So thus a positive corporate image will be formed in accordance with the expectations of the company.

Keywords: Deviations, Public Relations, Corporate Image
\end{abstract}

\section{A. PENDAHULUAN}

Seperti perusahaan lain pada umumnya, dituntut untuk menjaga hubungan yang harmonis terhadap publiknya, baik publik internal maupun publik eksternal perusahaan, mengingat hubungan perusahaan dengan pihak internal dan eksternal perusahaan akan memberi pengaruh terhadap citra pada perusahaan. Untuk itu, perusahaan menugaskan dan memercayakan tugas tersebut kepada Public Relations yang bekerja di bawah naungan 
perusahaan Public Relations yang ada pada saat itu telah mengerjakan tugas dan pekerjaannya dengan baik dalam menjaga citra perusahaan dan menangani permasalahanpermasalahan di perusahaan.

Hal tersebut dapat dilihat dari salah satu contoh kasus yang terjadi pada pertengahan tahun 2012, yang dimana pada saat itu terjadi konflik internal pada Sebuah perusahaan pemasok yang bergerak dalam bidang usaha jasa konstruksi, para karyawan melakukan aksi demo di halaman gedung perusahaan. Penyebab utama munculnya demo ini karena karyawan merasa keberatan dengan upah kerja karyawan pada saat itu sehingga melakukan aksi demo untuk meningkatkan upah kerja karyawan. Peranan Public Relations dirasakan sangat baik dalam usahanya menjadi fasilitator komunikasi antara manajemen dengan karyawan. Hal ini terlihat dalam komunikasi yang dilakukan saat berdialog dengan karyawan dan juga saat Public Relations menyampaikan segala keluh kesah serta tuntutan karyawan pada manajemen. Jadi disini Public Relations berwenang untuk mengumpulkan informasi sebanyak-banyaknya, mencari tahu penyebab konflik, menjadi mediator antara manajemen dengan karyawan serta membantu memberikan solusi pada manajemen untuk mengatasi konflik yang terjadi. Akhirnya pihak manajemen mengeluarkan keputusan untuk meningkatkan upah kerja karyawan sesuai dengan posisi kerja karyawan.

Dengan contoh kasus diatas, dapat dilihat bahwa Public Relations mempunyai peranan penting dalam mengatasi krisis pada perusahaan. Mengingat krisis yang terjadi dapat berdampak negatif terhadap citra perusahaan, sehingga dapat dikatakan Public Relations merupakan fungsi manajemen yang strategis.

Tetapi pada awal maret tahun 2013, memutuskan untuk menyerahkan semua tugas serta tanggung jawab Public Relations kepada sekretaris direktur perusahaan karena karyawan yang menduduki posisi Public Relations memutuskan untuk berhenti bekerja. Keputusan perusahaan yang seperti ini menyebabkan posisi serta tugas Public Relations perusahaan pada periode tahun 2013 sampai tahun 2015 jatuh pada posisi sekretaris direktur perusahaan, dan menyebabkan situasi dimana sekretaris direktur harus merangkap bekerja sebagai Public Relations perusahaan, tetapi sekretaris direktur tidak dapat mengelola konflik secara maksimal, karena tidak memiliki kewenangan dalam hal pengambilan keputusan, segala kebijakan yang diambil sepenuhnya merupakan kewenangan dari direktur utama. Sehingga hasil yang didapatkan tidak efektif. Padahal setiap perusahaan memerlukan posisi Public 
Relations yang dapat menjadi penengah perusahaan dan para konsumen, serta membutuhkan komunikasi antar perusahaan dengan perusahaan lainnya dan komunikasi dengan pelanggannya agar terjadi keharmonisan dan keselarasan serta agar terciptanya suatu interaksi yang baik bagi atasan, bawahan, dan pelanggan.

Pada dasarnya, Public Relations merupakan fungsi tertentu yang diperlukan oleh setiap organisasi, baik organisasi yang bersifat komersial maupun organisasi yang bersifat nonkomersial. Keberadaan Public Relations dalam suatu organisasi atau perusahaan adalah sebuah indikasi bahwa Public Relations memiliki peran penting dalam perputaran sistem dan manajemen yang ada dalam perusahaan atau organisasi. Keberadaan Public Relations mampu menyentuh dan menerobos aspek-aspek sosial dan kepentingan publik.

Dalam buku berjudul A Model for PR Education for Professional Practices yang dikeluarkan oleh International Public Relations Associations (IPRA), mendefinisikan Public Relations sebagai fungsi manajemen yang khas dan mendukung pembinaan, pemeliharaan jalur bersama antara organisasi dengan publiknya, menyangkut aktivitas komunikasi, pengertian, penerimaan dan kerjasama, melibatkan manajemen dalam persoalan atau permasalahan, mampu menanggapi opini publik, mendukung manajemen dalam mengikuti dan memanfaatkan perubahan secara efektif, bertindak sebagai sistem peringatan dini dalam mengantisipasi kecenderungan menggunakan penelitian serta teknik komunikasi yang sehat dan etis sebagai sarana utama (Rosady Roslan, 1998 : 16).

Menurut J.C.Seidel (Oemi, 2001 : 24-26), "Public Relations is the continuing process by which management endeavours to obtain goodwill and understanding of its customer, its employees, and the public at large, inwardly through self analysis and correction, outwardly through all mens of expressions." Yang mengandung arti Public Relations adalah sebuah proses yang berkelanjutan dari usaha-usaha manajemen, pegawainya, serta publik umumnya, kedalam dengan mengadakan analisis dan perbaikan terhadap diri sendiri, keluar dengan mengadakan pernyataan-pernyataan.

Menurut Cutlip \& Center yang dikutip oleh Frida Kusumastuti (2002 : 26), menyatakan tugas pokok Public Relations pada suatu perusahaan adalah:

1. Mendidik melalui kegiatan nonprofit suatu publik untuk menggunakan barang atau jasa instansinya.

2. Mengadakan usaha untuk mengatasi salah paham antara instansi dengan publik. 
3. Meningkatkan penjualan barang atau jasa.

4. Meningkatkan kegiatan perusahaan yang berkaitan dengan kegiatan masyarakat seharihari.

5. Mendidik dan meningkatkan tuntutan serta kebutuhan masyarakat akan barang dan jasa yang dihasilkan oleh perusahaan.

6. Mencegah pergeseran penggunaan barang atau jasa yang sejenis dari pesaing perusahaan oleh konsumen

Meskipun mempunyai tugas dan fungsi seperti diatas, tujuan utama Public Relations adalah menjalin hubungan yang baik antara pihak perusahaan dengan publiknya. Hubungan baik tersebut bukan semata-mata demi kepentingan perusahaan saja melainkan untuk keuntungan kedua belah pihak, perusahaan menikmati keuntungan dan manfaat dari hubungan yang baik itu publik pun menikmati keuntungan dan manfaat dari hubungan baik tersebut.

Public Relations mencakup semua bentuk komunikasi yang terselenggara antara organisasi yang bersangkutan dengan khalayak. Hal ini menjadi salah satu alasan mengapa banyak perusahaan mulai menyadari pentingnya sebuah Public Relations serta memerlukan Public Relations dalam menopang kinerja serta citra perusahaannya. Pentingnya citra sebuah perusahaan dikarenakan citra positif dapat memberikan kemudahan bagi perusahaan untuk berkomunikasi dan mencapai tujuan secara efektif, sedangkan citra negatif sebaliknya. Citra positif dapat digunakan sebagai pelindung terhadap kesalahan kecil, kualitas teknis atau fungsional sedangkan citra negatif dapat memperbesar kesalahan tersebut.

Citra menggambarkan pengalaman dan harapan konsumen atas kualitas pelayanan perusahaan dan citra mempunyai pengaruh penting terhadap manajemen atau dampak internal, dimana citra perusahaan yang kurang jelas dan nyata dapat mempengaruhi sikap karyawan (Sutojo, 2004: 60).

Dari latar belakang yang diuraikan dan diceritakan di atas, penulis ingin memberikan gambaran mengenai fungsi Public Relations dalam upaya meningkatkan citra perusahaan, mengingat begitu penting dampak yang ditimbulkan dari sebuah pencitraan positif pada perusahaan. Meskipun hingga pada saat ini, kita masih sering menjumpai kerancuan pandangan dan persepsi yang sehubungan dengan pengertian Public Relations. Padahal, apabila peran Public Relations dalam perusahaan atau organisasi dilaksanakan dengan baik 
akan menciptakan hubungan yang harmonis, baik secara internal maupun eksternal yang secara tidak langsung berpengaruh terhadap citra perusahaan. Sehingga peneliti mengidentifikasi masalah-masalah yang terjadi pada penelitian ini sebagai berikut: Mengenai bentuk penyimpangan tugas dan fungsi Public Relations dalam membentuk citra perusahaan.

Agar penelitian ini berjalan dengan sistematis, maka perlu di buat perumusan masalah sebagai berikut: Bagaimana bentuk penyimpangan tugas dan fungsi Public Relations dalam membentuk citra perusahaan?

Berdasarkan dengan rumusan masalah di atas, maka dapat di rumuskan tujuan penelitian ini adalah: Untuk mengetahui bentuk penyimpangan tugas dan fungsi Public Relations dalam membentuk citra perusahaan pada sebuah perusahaan pemasok yang bergerak dalam bidang usaha jasa konstruksi di Kota Batam.

Diharapkan dengan penelitian ini dapat memberikan manfaat dari segi akademisi yaitu: Sebagai bahan pengetahuan dan tambahan referensi bagi peneliti-peneliti lain, serta peningkatan wawasan dan pengetahuan dalam bidang komunikasi khususnya terkait dengan Public Relations dan citra perusahaan. Dan secara praktis: Diharapkan dapat membantu perusahaan sebagai bahan perbandingan dan pertimbangan dalam menentukan langkah untuk meningkatkan proses dalam membentuk citra perusahaan di masa yang akan datang.

\section{B. TINJAUAN PUSTAKA}

Komunikasi merupakan alat utama untuk menyempurnakan hubungan dalam organisasi. Tidak adanya komunikasi akan mengakibatkan timbulnya salah pengertian, dan bila dibiarkan akan mempengaruhi kehidupan organisasi, baik atasan maupun para pegawai dilingkungan instansinya sendiri. Komunikasi merupakan aktivitas dasar manusia sehari-hari, baik dalam komunikasi bermasyarakat atau dimana saja manusia bersosialisasi. Pendapat Hovland yang di kutip Effendy (2005 : 10) dalam bukunya Komunikasi Teori dan Praktek, menjelaskan bahwa Ilmu komunikasi adalah upaya yang sistematis merumuskan secara tegas asas-asas penyampaian informasi serta pembentukan pendapat dan sikap.

Komunikasi juga merupakan suatu aspek dari kehidupan manusia yang paling mendasar, penting, dan kompleks. Kehidupan sehari-hari kita sangat dipengaruhi oleh komunikasi kita sendiri dengan orang lain, bahkan oleh pesan yang berasal dari orang yang kita tidak tahu. Seperti yang dijelaskan oleh Watzlawick (1967 : 22) dalam tulisannya Pragmatics of Human 
Communication, bahwa seseorang tidak bisa tidak berkomunikasi (we can not not communication). Karena kekompleksan komunikasi yang seperti ini, maka Little John mengatakan, komunikasi adalah sesuatu yang sulit untuk didefinisikan. Sementara itu, menurut Ensiklopedia Bebas Berbahasa Indonesia, komunikasi adalah suatu proses penyampaian pesan dari satu pihak kepada pihak lain, agar terjadi saling mempengaruhi di antara keduanya.

Dalam proses komunikasi, ada lima elemen dasar yang dikemukakan oleh Harold Lasswell dengan istilah "Who Says What in Which Channel to Whom with What Effect". Kelima elemen dasar tersebut adalah Who (sumber atau komunikator), Says What (pesan), in Which Channel (Saluran), to Whom (Penerima), with What Effect (Efek atau dampak). Lima elemen dasar dari komunikasi yang dikemukakan oleh Harold Laswell di atas juga sangat berpengaruh bagi seorang praktisi Public Relations dalam menjalankan tugasnya.

Sebagai seorang Public Relation, salah satu tugasnya adalah berperan sebagai fasilitator komunikasi. Peran Public Relations dalam sebuah perusahaan atau organisasi adalah sebagai pendengar yang peka dan juga sebagai perantara komunikasi. Public Relations bekerja sebagai penghubung antara perusahaan dengan publiknya. Komunikasi akan selalu dijaga supaya berjalan dua arah dan memfasilitasi komunikasi tersebut dengan menyingkirkan segala rintangan sambil terus membuka jalur komunikasi. Tujuannya adalah memberi informasi yang dibutuhkan baik oleh instansi maupun publiknya untuk membuat suatu keputusan atau pandangan demi kepentingan bersama.

Dalam ilmu komunikasi, kita mengenal adanya teori komunikasi persuasif, yaitu komunikasi yang bersifat mempengaruhi audience atau komunikannya, sehingga bertindak sesuai dengan apa yang diharapkan oleh komunikator. Teori komunikasi persuasif ini juga dapat merefleksikan sebuah praktik Public Relations yang berusaha mencapai tujuan organisasi melalui persuasi.

Menurut K. Andeerson, komunikasi persuasif didefinisikan sebagai perilaku komunikasi yang mempunyai tujuan mengubah keyakinan, sikap atau perilaku individu atau kelompok lain melalui transmisi beberapa pesan.

Joseph A. DeVito (2011 : 377) menjelaskan komunikasi persuasif dalam buku Komunikasi Antarmanusia sebagai pembicaraan persuasif mengetengahkan pembicaraan 
yang sifatnya memperkuat, memberikan ilustrasi, dan menyodorkan informasi kepada khalayak. Akan tetapi tujuan pokoknya adalah menguatkan atau mengubah sikap dan perilaku, sehingga penggunaan fakta, pendapat, dan himbauan motivasional harus bersifat memperkuat tujuan persuasifnya.

Dari penjelasan tersebut, Joseph A.DeVito mengemukakan terdapat dua macam tujuan atau tindakan yang ingin kita capai dalam melakukan pembicaraan persuasif. Tujuan tersebut dapat berupa untuk mengubah sikap atau perilaku receiver atau untuk memotivasi perilaku receiver.

Perancangan pesan-pesan yang bersifat persuasif dapat digunakan oleh seorang Public Relations untuk meyakinkan pihak-pihak yang berhubungan dengan organisasi. Pesan-pesan persuasif yang efektif haruslah dirancang sedemikian rupa dengan fokus pada penerima, sehingga pesan dapat sesuai dengan tujuan. Perancangan pesan persuasif sangat penting bagi seorang Public Relations, karena setiap hari organisasi harus mengirimkan pesan-pesan dengan nada yang meyakinkan, baik kepada konsumen, pemasok, mitra bisnis, maupun pihak-pihak lainnya yang berhubungan dengan perusahaan atau organisasi, seperti mengenai bagaimana suatu aktifitas dan kegiatan harus diinformasikan, tentang tema, untuk berapa lama, sejauh mana dukungan dana, manajemen dan fasilitas, agar dapat memenuhi keinginan untuk tercapainya target sesuai dengan harapan perusahaan.

Selain dengan menggunakan teori komunikasi persuasif seperti yang telah dibahas di atas, praktisi Public Relations juga dapat memakai metode komunikasi dua arah (two way traffic communication) dalam tujuannya mengembangkan perusahaan. Komunikasi dua arah (two way traffic communication) menggambarkan sebuah orientasi Public Relations dimana organisasi dan publik saling menyesuaikan diri. Model ini berfokus pada penggunaan metode riset ilmu sosial untuk memperoleh rasa saling pengertian serta komunikasi dua arah antar publik dan perusahaan. Bagi seorang Public Relations, umpan balik yang diberikan oleh khalayak akan membawa perbaikan, perubahan, perkembangan sebagai efeknya. Umpan balik atau feedback akan dianalisa oleh praktisi Public Relations untuk menilai pendapat khalayak terhadap komunikasi yang telah dilakukan oleh Public Relations. Public Relations menganalisa apakah respon yang didapat positif sehingga berdampak baik terhadap citra atau malah negatif sehingga kurang menguntungkan posisi organisasi di mata masyarakat. 
Kegiatan Public Relations pada hakikatnya merupakan bagian dari teknik kegiatan berkomunikasi (technique of communication). Public Relations bertujuan untuk menciptakan menciptakan pengertian berdasarkan kebenaran, pengetahuan, dan informasi yang lengkap serta mediator yang memecahkan konflik kepentingan. Oleh karena itu, dapat dikatakan bahwa kegiatan Public Relations merupakan suatu proses komunikasi, namun tidak semua proses komunikasi adalah kegiatan Public Relations.

Karena berbeda dengan kegiatan komunikasi lainnya, kegiatan Public Relations senantiasa berkenaan dengan kegiatan penciptaan pemahaman melalui pengetahuan, dan melalui kegiatan-kegiatan tersebut diharapkan akan muncul suatu dampak, yakni berupa perubahan yang positif. Dengan demikian, dapat dikatakan bahwa kunci kesuksesan seorang Public Relations adalah melalui komunikasi. Artinya, keberhasilan Public Relations untuk mencapai tujuannya bergantung kepada sejauh mana Public Relations itu dapat menjalin hubungan yang baik dengan masyarakatnya, baik khalayak internal maupun eksternal.

Melalui komunikasi pula, Public Relations dapat menyampaikan informasi, mendorong serta memotivasi, mempersuasi, mempengaruhi, dan mengubah sikap khalayak atau publik. Demikian pula dalam tugas seorang Public Relations harus dapat membina hubungan baik, saling pengertian, saling membutuhkan, dan saling mendukung adanya organisasi di satu pihak dengan keberadaan masyarakat di lain pihak. kunci kesuksesan suatu komunikasi dalam kegiatan Public Relations, sangat tergantung pada proses pelaksanaan komunikasi yang efektif.

Bagi seorang praktisi Public Relations, Fungsi utamanya adalah menumbuhkan dan mengembangkan hubungan baik antar lembaga atau organisasi dengan publiknya, internal maupun eksternal dalam rangka menanamkan pengertian, menumbuhkan motivasi dan partisipasi publik dalam upaya menciptakan iklim pendapat atau opini publik yang menguntungkan lembaga organisasi.

Menurut Kasali dalam Ruslan (2010 : 11), mengatakan bahwa fungsi Public Relations bertujuan menciptakan dan mengembangkan persepsi terbaik bagi suatu lembaga, organisasi, perusahaan, atau produknya terhadap segmen masyarakat yang kegiatannya baik secara langsung maupun tidak langsung mempunyai dampak bagi masa depan organisasi, lembaga, perusahaan atau produknya. 
Dalam operasional Public Relations dikenal dengan penemuan fakta (fact finding), perencanaan (planning), pengkomunikasian (communicating), dan pengevaluasian atau pemantauan (evaluating). Menciptakan citra perusahaan atau lembaga merupakan tujuan akhir dari suatu aktivitas program kerja Public Relations.

Hal ini sama seperti yang dikemukakan oleh Cutlip dan Center (2005 : 126) mengenai empat proses kerja Public Relations, yaitu :

\section{Defining the Problem (Fact Finding)}

Tahap pertama ini mencakup penyelidikan dan memantau pengetahuan, opini, sikap dan perilaku pihak-pihak yang terkait dengan dan dipengaruhi oleh tindakan dan kebijaksanaan perusahaan. pada dasarnya ini adalah fungsi inteligen organisasi. fungsi ini menyediakan dasar untuk semua langkah dalam proses pemecahan problem dengan menentukan "Apa yang sedang terjadi saat ini?"

\section{Planning and Programming}

Informasi yang dikumpulkan dalam langkah pertama digunakan untuk membuat keputusan tentang program publik, strategi tujuan, tindakan dan komunikasi, taktik, dan sasaran. Tahap ini akan mempertimbangkan temuan dari langkah dalam membuat kebijakan dan program organisasi. Tahap kedua ini akan menjawab pertanyaan "Berdasarkan apa kita tahu tentang situasi, dan apa yang harus kita lakukan atau apa yang harus kita ubah?"

\section{Taking Action and Communicating}

Tahap ketiga adalah mengimplementasikan program aksi dan komunikasi yang di desain untuk mencapai tujuan spesifik untuk masing-masing publik dalam rangka mencapai tujuan program. Pertanyaan dalam tahap ini adalah "Siapa yang harus melakukan dan menyampaikannya, dan kapan, dimana, dan bagaimana caranya?"

\section{Evaluating the Program}

Tahap terakhir dalam proses ini adalah melakukan penilaian atas persiapan, implementasi, dan hasil dari program. Penyesuaian akan dilakukan sembari program diimplementasikan, dan didasarkan pada evaluasi atas umpan balik tentang bagaimana program itu berhasil atau tidak. Program akan dilanjutkan atau dihentikan setelah menjawab pertanyaan "Bagaimana keadaan kita sekarang atau seberapa baik tahap yang telah kita lakukan?" 
Peranan Public Relations yang luas menyangkut hubungan dengan berbagai pihak dan tidak hanya sekedar berbentuk relations dalam arti sempit, karena personal relations mempunyai peranan yang cukup besar dalam melakukan kampanye Public Relations. Bagaimana meningkatkan kesadaran, pengertian dan pemahaman tentang aktivitas perusahaan atau lembaga, termasuk membentuk sikap yang menyenangkan (favorable), iktikad baik (goodwill), toleransi (tolerance), saling pengertian (mutual understand), saling mempercayai (mutual confidence), saling menghargai (mutual appreciation), dan pada akhirnya akan menciptakan citra baik (good image).

Public Relations yang menyampaikan pesan-pesan secara tepat sasaran mampu menumbuhkan citra positif dan menghimpun awareness dari publik terhadap perusahaan. Citra yang baik akan menumbuhkan reputasi yang baik pula dari suatu perusahaan.

Frank Jefkins dalam Ardianto dan Soemirat (2004 : 114), menyimpulkan bahwa secara umum citra diartikan sebagai kesan seseorang atau individu tentang suatu yang muncul sebagai hasil dari pengetahuan dan pengalamannya. Sementara menurut David A. Arker, John G. Mayer dalam Nova (2011 : 298) citra adalah seperangkat anggapan, impresi atau gambaran seseorang atau sekelompok orang mengenai suatu objek bersangkutan.

Salah satu jenis citra adalah citra perusahaan. Citra perusahaan ini terbentuk dari banyak hal, seperti misalnya dari sejarah atau riwayat hidup perusahaan yang gemilang, keberhasilan dan stabilitas di bidang keuangan, kualitas produk, keberhasilan ekspor, hubungan industri yang baik, reputasi sebagai pencipta lapangan kerja, kesediaan turut memikul tanggung jawab sosial dan komitmen mengadakan riset. Memiliki suatu citra perusahaan yang cemerlang dan positif, jelas merupakan keinginan dari setiap perusahaan, termasuk yang diinginkan oleh perusahaan.

Citra perusahaan di mata publik dapat terlihat dari pendapat atau pola pikir pada saat mempersepsikan realitas yang terjadi. Terbentuknya citra perusahaan karena adanya persepsi. Menurut Kotler dalam Nova (2011: 97) persepsi adalah pandangan seseorang dalam menafirkan suatu peristiwa berdasarkan informasi yang diterimanya. Untuk mendapatkan citra yang diinginkan, perusahaan harus memahami secara persis proses yang terjadi ketika publik menerima informasi mengenai kenyataan yang terjadi.

Citra yang baik dari suatu organisasi merupakan aset yang sangat penting karena citra mempunyai suatu dampak persepsi publik dan operasi organisasi dalam berbagai hal. Setiap 
perusahaan harus mempunyai citra di masyarakat, dan citra itu sendiri dapat berperingkat baik, sedang, atau buruk. Citra buruk melahirkan dampak yang negatif bagi operasi bisnis perusahaan dan juga melemahkan kemampuan perusahaan untuk bersaing.

Dari konsep di atas, maka model penelitian berdasarkan paparan pembahasan dan permasalahan yang diangkat oleh peneliti dapat ditunjukan dalam gambar berikut ini :

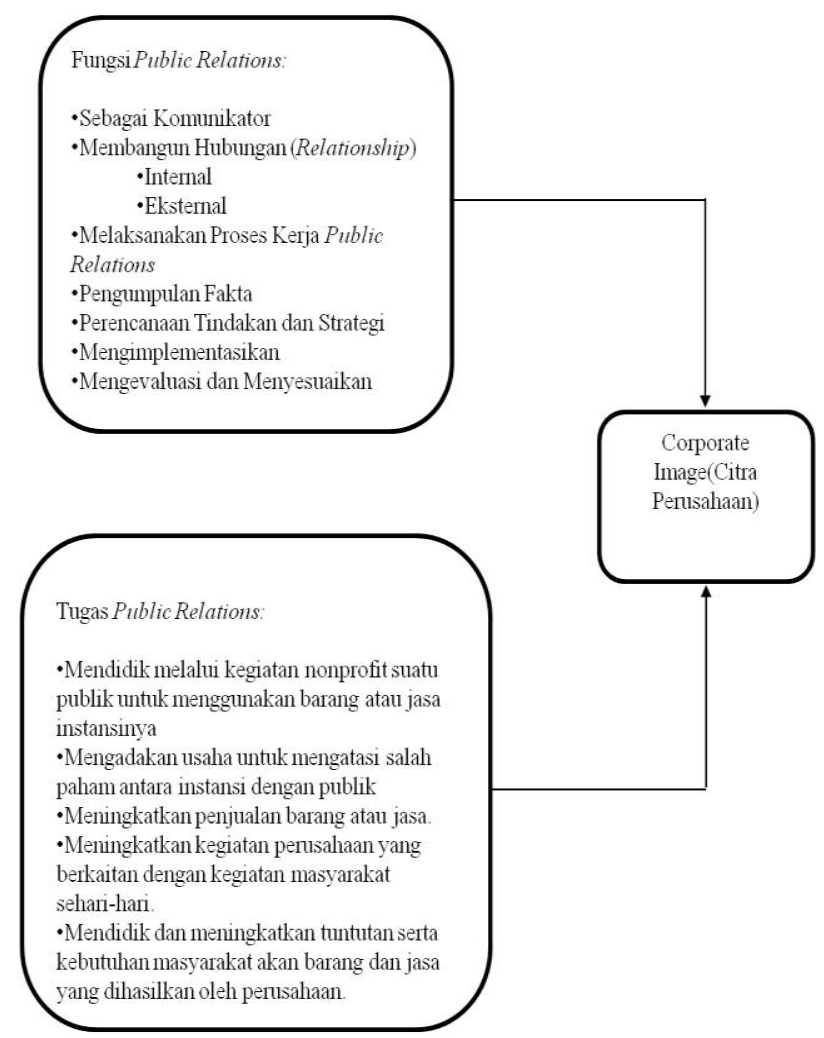

\section{METODE PENELITIAN}

\section{Konseptualisasi Penelitian}

Penelitian ini menggunakan metode penelitian pendekatan kualitatif dengan metode studi kasus (case study). Penelitian kualitatif yaitu suatu pendekatan penelitian yang menggunakan data berupa kalimat tertulis atau lisan, perilaku, fenomena, peristiwa-peristiwa dan pengetahuan atau obyek studi. Pendekatan ini menitikberatkan pada pemahaman, pemikiran, dan persepsi peneliti. Studi kasus didefinisikan sebagai fenomena khusus yang dihadirkan 
dalam suatu konteks yang terbatasi (bounded text), meski batas-batas antara fenomena dan konteks tidak sepenuhnya jelas (Moleong, 2008 : 4-5).

Alasan penulis menggunakan jenis penelitian deskriptif kualitatif karena dengan jenis penelitian ini mampu memberikan gambaran yang menyeluruh dan jelas terhadap situasi satu dengan situasi sosial yang lain atau dari waktu tertentu dengan waktu lain, atau dapat menemukan pola-pola hubungan antara aspek tertentu dengan aspek yang lain dan dapat menemukan hipotesis dan teori, yaitu menggambarkan sebuah proses dan seperangkat kategori atau pola tentang bagaimana bentuk dari penyimpangan tugas dan fungsi Public Relations dalam pembentukan citra perusahaan.

\section{Sumber Data}

Pengambilan sumber data dalam penelitian ini menggunakan teknik purposive sampling. Menurut Sugiyono (2008 : 218) purposive sampling adalah teknik pengambilan sampel sumber data dengan pertimbangan tertentu yakni sumber data dianggap paling tahu tentang apa yang diharapkan, sehingga mempermudah peneliti menjelajahi obyek atau situasi sosial yang sedang diteliti. Objek dalam penelitian ini adalah keseluruhan sumber daya manusia yang ada di PT Sempurna Readymix Concrete. Subjek penelitian dalam penelitian ini adalah tiga karyawan dari perusahaan tersebut.

\section{Teknik Pengumpulan Data}

Teknik pengumpulan data yang digunakan dalam penelitian ini adalah :

1. Observasi : peneliti mengobservasi fakta atau fenomena terkait dengan unsur serta bauran tugas dan fungsi Public Relations di PT Sempurna Readymix Concrete Kota Batam.

2. Wawancara : informasi didapatkan melalui wawancara dengan General Manager dan beberapa karyawan relevan dengan konteks penelitian yang sekiranya dapat membantu memberikan informasi. Wawancara dilakukan dengan menggunakan metode wawancara semiterstruktur, dimana dalam pelaksanaannya lebih bebas. Tujuan dari wawancara ini adalah untuk menemukan permasalahan lebih terbuka, dimana pihak yang diajak wawancara diminta pendapat, terkait mengenai peran dan fungsi Public Relations di perusahaan.

3. Studi kepustakaan atau studi dokumentasi : peneliti mengumpulkan data sekunder penelitian melalui catatan, data, ataupun dokumen dari masa lampau perusahaan. 


\section{Instrumen Penelitian}

Instrumen penelitian menurut Suharsimi Arikunto (2002 : 149) merupakan alat bantu bagi peneliti dalam mengumpulkan data agar pekerjaannya lebih mudah dan hasilnya lebih baik, dalam arti lebih cermat, lengkap, dan sistematis, sehingga mudah untuk diolah. Instrumen yang digunakan oleh peneliti dalam hal ini adalah instrumen pokok dan instrumen penunjang. Instrumen pokok dalam penelitian ini adalah peneliti sendiri. peneliti merupakan alat atau instrumen pengumpul data utama, karena peneliti adalah manusia dan hanya manusia yang dapat berhubungan dengan responden atau objek lainnya, serta mampu memahami dan menilai berbagai bentuk dari interaksi di lapangan. Oleh karena itu, peneliti juga berperan serta dalam pengamatan atau berperan sebagai participant observation (Moleong, 2008 : 9).

Untuk membantu peneliti sebagai instrumen pokok, maka peneliti membuat instrumen penunjang. Dalam penyusunan instrumen penunjang tersebut, Suharsimi Arikunto (2002 : 153) mengemukakan pemilihan yang akan digunakan peneliti ditentukan oleh tujuan penelitian, sampel penelitian, lokasi, pelaksana, biaya dan waktu, dan data yang ingin diperoleh. Dari tujuan yang telah dikemukakan tersebut, dalam penelitian ini peneliti menentukan instrumen penunjang yang digunakan yaitu pedoman wawancara serta alat perekam.

Dalam penelitian kualitatif, instrumen utamanya adalah manusia, karena itu yang diperiksa adalah validitas atau keabsahan datanya (Dwilestari, 2012 : 87). Untuk menguji keabsahan data dalam penelitian ini, peneliti menggunakan teknik pengujian validitas data yaitu uji credibility atau uji kredibilitas dengan melakukan teknik triangulasi sumber yang dimana dilakukan dengan cara mengecek data yang diperoleh melalui beberapa sumber sehingga menghasilkan suatu kesimpulan yang selanjutnya diminta kesepakatan dengan sumber data tersebut.

\section{Metode Analisis Data}

Metode analisis data yang peneliti gunakan adalah metode analisis data deskriptif, karena penelitian ini bertujuan untuk mendeskripsikan penyimpangan tugas dan fungsi Public Relations dalam membentuk citra perusahaan. Menurut Arikunto (2002 : 250) metode analisis deskriptif merupakan penelitian bukan eksperimen, karena tidak dimaksudkan untuk 
mengetahui akibat dari suatu perlakuan. Dengan penelitian deskriptif peneliti hanya bermaksud menggambarkan atau menerangkan gejala yang sedang terjadi.

Metode analisis ini juga digunakan untuk mendapatkan suatu gambaran yang jelas yang berkaitan dengan pokok permasalahan yang diteliti yaitu penyimpangan tugas dan fungsi Public Relations dalam membentuk citra perusahaan.

Adapun prosedur dalam menganalisis data kualitatif, menurut Miles dan Huberman (1984) dalam Sugiyono (2008 : 91-99) adalah sebagai berikut :

1. Pengumpulan data : proses pengumpulan data dapat dilakukan dengan berbagai macam cara melalui wawancara, pengamatan, observasi, dan dokumentasi. Pengumpulan data dilakukan untuk memperoleh informasi yang dibutuhkan untuk mencapai tujuan penelitian.

2. Reduksi data : mereduksi data berarti merangkum dan memilih hal-hal pokok serta memfokuskan pada hal-hal yang penting, dicari tema dan polanya. Dengan demikian data yang telah direduksi akan memberikan gambaran yang lebih jelas, dan mempermudah peneliti untuk melakukan pengumpulan data selanjutnya, dan mencarinya bila diperlukan.

3. Penyajian data : setelah data direduksi, maka langkah selanjutnya adalah mendisplaykan data. Penyajian data bisa dilakukan dalam bentuk uraian singkat, bagan, hubungan antar kategori, flowchart dan sejenisnya dengan menggunakan teks yang bersifat naratif.

4. Kesimpulan atau verifikasi : Langkah terakhir dalah penarikan kesimpulan dan verifikasi. Kesimpulan awal yang dikemukakan bersifat sementara, dan akan berubah bila tidak ditemukan bukti-bukti yang kuat yang mendukung pada tahap pengumpulan data berikutnya. Tetapi apabila kesimpulan yang dikemukakan pada tahap awal, didukung oleh bukti-bukti yang valid dan konsisten ketika peneliti mengumpulkan data di lapangan, maka kesimpulan yang dikemukakan merupakan kesimpulan yang kredibel.

\section{HASIL DAN PEMBAHASAN}

Dalam penelitian ini, sumber data utamanya adalah hasil wawancara yang telah dilakukan dengan tiga narasumber yang dimana terlibat dalam fokus permasalahan pada penelitian ini, yaitu Bapak Suyono selaku General Manager, Ibu Erica selaku Operation Secretary (OPS) yang dimana untuk saat ini melaksanakan tugas dan fungsi sebagai Public 
Relations pada, serta Ibu Elistina Xie, yang dimana menduduki posisi sebagai Public Relations terakhir di perusahaan.

Dari pembahasan yang telah diuraikan, dapat dilihat bahwa peranan Operational Secretary (OPS) sebagai Public Relations telah cukup berperan dalam pelaksanaan fungsi sebagai Public Relations, tetapi pelaksanaan tersebut digabungkan dengan pekerjaan sekretaris operasional sehingga fungsi Public Relations itu sendiri menjadi kurang efisien dan kurang optimal. Padahal peranan Public Relations dalam meningkatkan citra perusahaan sangat penting, karena jika peran dan fungsi Public Relations dapat dijalankan dengan baik maka citra perusahaan dapat meningkat, tapi sebaliknya, jika peran dan fungsi Public Relations tidak dapat dijalankan dengan baik, maka citra perusahaan tidak dapat meningkat. Berikut merupakan struktur organisasi pada PT Sempurna Readymix Concrete Kota Batam.

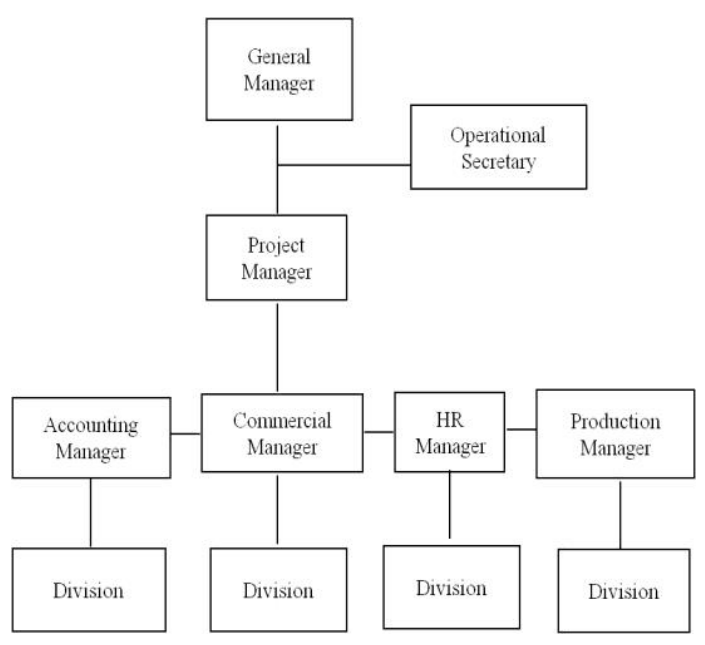

Dari struktur organisasi di atas dapat dilihat bahwa, posisi Operational Secretary (OPS) berada dibawah General Manager perusahaan, dengan deskripsi pekerjaan sebagai berikut :

1. Menyusun dan menyiapkan peralatan dan keperluan yang dibutuhkan pada rapat perusahaan.

2. Memantau dan memeriksa masalah atau kejadian yang dilaporkan dari divisi-divisi pada saat rapat. 
3. Menyusun, mencatat dan menyimpan hasil dari setiap pertemuan rapat, kemudian dibagikan kepada setiap divisi.

4. Memberikan respon dan tanggapan dengan cepat terhadap permasalahan-permasalahan pada perusahaan.

5. Merespon atau menanggapi pengaduan-pengaduan.

6. Mengatur dan menyimpan dokumen-dokumen perusahaan.

7. Memantau dan melaporkan masalah-masalah yang terjadi di lapangan kepada Team Manajemen secara berkala.

8. Mengadakan dan menyiapkan keperluan-keperluan untuk event-event rutin perusahaan.

9. Membangun dan menjaga citra positif perusahaan.

10. Membangun dan menciptakan iklim kerja yang harmonis dalam perusahaan.

11. Menjaga hubungan harmonis antara perusahaan dengan pihak internal dan pihak eksternal perusahaan.

12. Menawarkan produk perusahaan dengan menyebarkan katalog terhadap calon pelanggan yang berpotensial.

Pada bagian ini, peneliti akan mendeskripsikan hasil dari penelitian dengan menghubungkan fokus-fokus penelitian yang dipakai dalam penelitian yaitu :

\section{Fungsi Public Relations sebagai komunikator}

Didalam perannya Operational Secretary (OPS) sebagai Public Relations harus dapat melaksanakan fungsi sebagai komunikator. Fungsi ini sangat dibutuhkan dalam sebuah perusahaan untuk menjadi jembatan antara perusahaan dengan publik atau antara pihak manajemen perusahaan dengan karyawan perusahaan, sehingga dapat tercapai saling pengertian (Mutual Understanding) antara kedua belah pihak.

Dalam hal ini peranan Operational Secretary (OPS) dalam pelaksanaan fungsi Public Relations sebagai komunikator adalah. menjadi juru bicara perusahaan dalam proses penyampaian informasi dan sebagai penyambung lidah dari team manajemen serta menjaga hubungan yang harmonis antara bagian-bagian departemen lain, dan tentunya juga dengan masyarakat.

Melalui perbedaan pernyataan yang dinyatakan oleh Bapak Suyono dan Ibu Erica dalam wawancara, peneliti dapat menyimpulkan pelaksanaan fungsi Public Relations sebagai komunikator memiliki lebih dari satu komunikator atau juru bicara yang mewakili 
perusahaan untuk "berbicara" terhadap publik. Meskipun tidak dapat dipungkiri bahwa aktivitas kedua pihak bertujuan untuk membangun citra perusahaan, tetapi hasil yang didapatkan apabila kedua pihak melaksanakan fungsi Public Relations sebagai komunikator secara bersamaan hasil yang didapatkan akan tidak optimal dan juga tidak efisien. Selain itu, penerapan sistem tersebut tidak sesuai dengan penggunaan konsep Public Relations dalam perusahaan seperti yang dikemukan oleh Morrisan (2008 : 13), yaitu :

"Suatu perusahaan yang memiliki hubungan dengan khalayak luas sudah dapat dikatakan memerlukan suatu departemen Public Relations tersendiri beserta staf lengkap.”

Selain itu, seperti yang dibahas pada penelitian terdahulu yang digunakan peneliti dengan judul "Public Relations dan Kesalahpahaman Publik Atas Pemaknaan Profesi", Prida menyatakan :

"Kesalah pahaman yang lain yang saat ini marak dimengerti masyarakat adalah sebagian orang mengacaukan Public Relations dengan aktivitas dan bagianbagiannya"

jadi peneliti dapat menyimpulkan bahwa salah satu penyebab lain yang membedakan antara pernyataan dari Bapak Suyono dan Ibu Erica merupakan contoh bentuk kesalahpahaman dan keliruan antara aktivitas Public Relations dengan Public Relations itu sendiri.

\section{Fungsi Public Relations dalam membangun hubungan internal dan eksternal perusahaan}

Kegiatan internal dan eksternal yang diadakan oleh Public Relations dapat memberikan dampak yang positif bagi perusahaan karena dengan adanya kegiatan tersebut akan meningkatkan rasa kepercayaan publik dan juga dapat membangun hubungan yang harmonis antara perusahaan dengan publiknya, baik publik internal maupun publik eksternal perusahaan.

Operational Secretary (OPS) yang dimana berfungsi sebagai Public Relations Sebuah perusahaan pemasok yang bergerak dalam bidang usaha jasa konstruksi melakukan serangkaian rencana, tujuan, kegiatan, serta tindak lanjut untuk meningkatkan citra perusahaan. Dalam hal ini tindak lanjut Operational Secretary (OPS) sebagai Public Relations dalam meningkatkan citra perusahaan yaitu: 
1. Melanjutkan pelaksanaan tugas-tugas serta fungsi Public Relations sesuai dengan ketentuan perusahaan terhadap Public Relations sebelumnya.

2. Merespon atau menanggapi pengaduan-pengaduan yang disampaikan oleh pelanggan.

Dari kegiatan-kegiatan yang dilakukan oleh Operational Secretary (OPS) sebagai Public Relations, peneliti dapat menyimpulkan Operational Secretary (OPS) telah melaksanakan fungsi sebagai Public Relations tetapi hasil yang di dapatkan kurang optimal karena peran Operations Secretary (OPS) dalam kegiatannya lebih cenderung bersifat satu arah kepada publik internal, sedangkan publik eksternal kurang diperhatikan. Operational Secretary (OPS) tidak dapat berfungsi sebagai Public Relations secara optimal dikarenakan Operational Secretary (OPS) harus mengerjakan pekerjaan administrasi lain yang harus dikerjakan oleh Operational Secretary (OPS) yang dimana menyita waktu dan fokus sehingga menyebabkan Operational Secretary (OPS) cenderung berada di dalam perusahaan daripada turun langsung ke lapangan, serta keterbatasan sumber daya yang dapat digunakan menjadi hambatan-hambatan yang dihadapi oleh Operational Secretary (OPS) dalam melaksanakan tugas dan fungsinya sebagai Public Relations.

\section{Fungsi Public Relations dalam melaksanakan proses kerja Public Relations}

Didalam perannya Operational Secretary (OPS) sebagai Public Relations harus dapat bergerak sebagai perencana dan penangung jawab atas rencana-rencana yang dijalankan.

Setelah melakukan penelitian dan wawancara terkait manajemen Public Relations yang diaplikasikan Operational Secretary (OPS) dalam melaksanakan tugas dan fungsi sebagai Public Relations, langkah-langkah yang dilakukan Operational Secretary (OPS) sudah sesuai dengan teori proses kerja Public Relations meskipun dalam aktivitasnya berbeda-beda. Seperti yang dikatakan Ruslan (2010 : 37), setiap sistem manajemen dalam perusahaan atau organisasi yang satu dengan lainnya akan berbeda dalam bentuk strukturalisasi manajemen dan operasi usaha produk dan pelayanan jasa tertentu, sistem manajemen pemasaran, keuangan, struktur organisasi sumber daya manusia, dan sebagainya. Termasuk peran dan fungsi Public Relations dalam manajemen perusahaan untuk mencapai tujuan utamanya saling berbeda satu sama lain.

Pengumpulan fakta yang dilakukan oleh operational Secretary (OPS) melalui laporanlaporan dari lapangan, kemudian disusun dan didiskusikan dalam rapat internal akhir bulan. Perencanaan tindakan dan strategi yang dilakukan adalah dengan menghubungkan bagian 
atau karyawan yang bersangkutan dengan masalah yang terjadi, kemudian mendiskusikan suatu perencanaan atau penyelesaian terhadap masalah yang terjadi. Pengimplementasian kemudian akan dicoba terapkan atau diimplementasikan di lapangan sesuai apa yang dibahas dan rencanakan di hasil rapat. Dan yang terakhir evaluasi dilakukan pada rapat internal akhir bulan yang berikutnya untuk melihat hasil dari rencana atau strategi yang diimplementasikan yang kemudian didiskusikan kembali setelah Operational Secretary (OPS) mengumpulkan fakta kembali yang didapat melalui feedback dari karyawan atau bagian yang bersangkutan.

Jadi dapat dilihat bahwa langkah-langkah yang telah diterapkan oleh Operational Secretary (OPS) sesuai dengan teori proses kerja Public Relations menurut Cutlip, Center dan Broom, meskipun dalam aktivitasnya berbeda-beda. Proses pelaksanaan rapat internal pada setiap akhir bulan yang diterapkan oleh Operational Secretary (OPS) telah dilaksanakan dengan cukup baik, tetapi akan lebih baik lagi apabila penerapan tersebut tidak hanya diterapkan pada pelaksanaan rapat internal akhir bulan perusahaan, melainkan pada semua kegiatan-kegiatan yang dilaksanakan Operational Secretary (OPS) sebagai Public Relations.

\section{E. KESIMPULAN DAN SARAN}

Berdasarkan hasil pembahasan analisis data penelitian mengenai penyimpangan tugas dan fungsi Public Relations dalam membentuk citra perusahaan yang telah dilakukan, maka dapat diambil kesimpulan dari penelitian ini sebagai berikut :

Bahwa apabila tugas dan fungsi Public Relations dilaksanakan dengan baik akan menjadi alat yang ampuh untuk memperbaiki dan mengembangkan peraturan, budaya organisasi, suasana kerja yang kondusif, dan motivasi dalam meningkatkan kinerjanya karyawan, serta membentuk citra atau image positif publik terhadap perusahaan. Pelaksanaan kegiatan Public Relations dalam upaya membangun citra perusahaan belum dapat dikatakan optimal karena perusahaan belum memiliki bagian khusus dalam menangani tugas dan fungsi Public Relations, melainkan melimpahkan tugas dan fungsi Public Relations tersebut pada Operational Secretary (OPS). Kegiatan-kegiatan yang dilakukan Operational Secretary (OPS) dalam melaksanakan tugas dan fungsi Public Relations antara lain sebagai komunikator, sebagai pembangun hubungan internal dan eksternal perusahaan, serta melaksanakan tugas-tugas Public Relations berdasarkan proses kerja Public Relations, yaitu mengumpulkan fakta, merencanakan tindakan dan strategi, mengimplementasikan, dan 
evaluasi. Pelaksanaan kegiatan Public Relations yang dilakukan oleh Operational Secretary (OPS) diarahkan dan dibantu oleh team manajemen perusahaan dan dengan tidak adanya bagian Public Relations secara tersendiri, keterbatasan sumber daya yang dapat digunakan, serta pekerjaan administrasi lain yang harus dikerjakan oleh Operational Secretary (OPS) yang dimana menyita waktu dan fokus merupakan hambatan yang dihadapi oleh Operational Secretary (OPS) dalam melaksanakan tugas dan fungsi sebagai Public Relations.

Berdasarkan hasil penelitian yang telah dilakukan, berikut saran yang dapat diajukan oleh peneliti :

Sebaiknya seorang Public Relations dalam menjalankan tugasnya terlebih dahulu memahami kegiatan Public Relations, sehingga mampu menjalin, membina, dan menjaga hubungan baik dengan publik baik internal maupun ekternal perusahaan. Selain itu, sebaiknya Operational Secretary (OPS) dapat lebih memperluas pengetahuannya dalam menjalankan tugas dan fungsinya sebagai Public Relations. Sehingga publik perusahaan baik publik internal maupun publik eksternal akan merasa terbantu, nyaman berkomunikasi, dan tidak dipersulit dalam mengatasi permasalahan yang terjadi. Sebaiknya team manajemen perusahaan memisahkan antara pekerjaan Operation Secretary (OPS) dengan pekerjaan Public Relations sehingga kedua posisi pekerjaan tersebut dapat dilaksanakan secara lebih fokus dan lebih baik lagi.

Team manajemen dan Operational Secretary (OPS) hendaknya lebih saling berkoordinasi lagi sehingga tujuan perusahaan dapat tercapai sesuai dengan apa yang diharapkan. Team manajemen juga hendaknya mendengar masukan-masukan yang diberikan oleh Operational Secretary (OPS) dalam upaya peningkatan pelayanan dan membangun keakraban sehingga mampu meningkatkan citra perusahaan.

Bagi peneliti lain, diharapkan dapat bermanfaat bagi peneliti lain dalam mengembangkan penelitian dan disarankan untuk mencari dan membaca referensi lain lebih banyak lagi agar hasil penelitian selanjutnya akan semakin baik serta dapat memperoleh ilmu pengetahuan yang baru. 


\section{DAFTAR PUSTAKA}

Abdurrachman, Oemi. (2001). Dasar-Dasar Public Relations. PT. Citra Aditya Bakti. Bandung.

Ardianto, Elvinaro dan Soleh, Soemirat. (2004). Dasar-Dasar Public Relations. Cetakan Ketiga. PT. Remaja Rosdakarya. Bandung.

Arikunto, Suharsimi. (2002). Prosedur Penelitian Suatu Pendekatan Praktek. Cetakan Kesebelas. PT. Rhineka Cipta. Jakarta.

Cutlip, Scott M, Center, Allen H, Broom, Glenn M. (2005). Effective Public Relations. Cetakan Kedelapan. PT. Kencana Perdana Media. Jakarta.

Devito, Joseph A. (2011). Komunikasi Antarmanusia. Cetakan Kelima. Karisma Publishing Group. Tangerang.

Effendy, Onong Uchana. (2005). Ilmu Komunikasi Teori dan Praktek. PT. Remaja Rosdakarya. Bandung.

Moleong, Lexy J. (2014). Metode Penelitian Kualitatif. Cetakan Ketiga puluh tiga. PT. Remaja Rosdakarya. Bandung.

Morissan. (2008). Manajemen Media Penyiaran: Strategi Mengelola Radio dan Televisi. Kencana Prenada Media Group. Jakarta.

Nova, Firsan. (2011). Crisis Public Relations. PT. Raja Grafindo Persada. Jakarta.

Putra, Nusa dan Dwilestari, Ninin. (2012). Penelitian Kualitatif PAUD. PT. Raja Grafindo Persada. Jakarta.

Rumanti, Maria Assumpta. (2005). Dasar-Dasar Public Relations: Teori dan Praktek. PT. Gramedia Widiasarana Indonesia. Jakarta.

Ruslan, Rosady. (2010). Manajemen Public Relations dan Media Komunikasi. PT. Raja Grafindo Persada. Jakarta.

Sugiyono. (2008). Metode Penelitian Kuantitatif Kualitatif dan R\&D. Alfabeta. Bandung.

Watzlawick, Belvin, and Johnson. (2011). Pragmatics of Human Communication: A Study of Interactional Patterns, Pathologies, and Paradoxes. Cetakan Pertama. W. W. Norton. New York. 